\title{
IMPACT OF LEMONGRASS (CYMBOPOGON CITRATUS) AND ROSELLE (HIBISCUS SABDARIFFA) ON BLOOD METABOLITES AND FECAL ANTICOCCIDIAL EFFECT OF SAIDI EWES
}

\author{
M. A. M. Abdullah ${ }^{1}$, MW. H. Daghash ${ }^{1}$, Asmaa H. M. Moneeb ${ }^{2}$, Wafaa G. Mahmoud ${ }^{3}$ and \\ M. G. M. Bakheet ${ }^{1}$, \\ ${ }^{1}$ Department of Animal Production, Faculty of Agriculture, Assiut University, Assiut, Egypt. \\ ${ }^{2}$ Department of Dairy Science, Faculty of Agriculture, Assiut University, Assiut, Egypt. \\ ${ }^{3}$ Department of Parasitology, Faculty of Veterinary Medicine, New Valley University, New Valley, Egypt.
}

\section{SUMMARY}

\begin{abstract}
$\mathrm{T}$
Wwenty-eight pregnant Saidi ewes were assigned to 4 treatments to study the influence of dietary Lemongrass and Roselle on blood metabolites, antioxidant status and anticoccidial effect. The experiment lasted for 75 days ( 15 before parturition and 60 after parturition). The treatments were: (1) CON group, animals received control diet without additives, consist of concentrate mixture (CM) and wheat straw; (2) LG group, animals fed control diet plus 4g Lemongrass/ kg dry matter (DM) of CM: (3) RO group, animals fed control diet plus 4g Roselle / $\mathrm{kg}$ DM of CM and (4) LGRO group, animals fed control diet plus (2g Lemongrass $+2 \mathrm{~g}$ Roselle) $/ \mathrm{kg}$ DM of CM. Blood and feces samples were taken at the end of the trial to determine some of blood metabolites and parasitic number. Dietary LGRO decreased $(\mathrm{P}<0.05)$ plasma protein and albumin while the ewes fed LG had the highest $(\mathrm{P}<0.05)$ concentration of globulin. Plasma creatinine concentration was lower $(\mathrm{P}<0.05)$ in treatment groups compared to $\mathrm{CON}$ group. There was a significant increase in plasma cholesterol concentration of LG and RO groups, while LGRO group had the lowest concentration of plasma total cholesterol $(\mathrm{P}<0.05)$ compared with other ones. Also, feeding with $\mathrm{LG}$ and LGRO had negative effect on the level of alanine aminotransferase and aspartate aminotransferase enzymes. Ewes fed RO had the highest $(\mathrm{P}<0.05)$ level of LDH enzyme compared with other groups. Dietary RO decreased $(\mathrm{P}<0.05)$ triioidothyronine $\left(\mathrm{T}_{3}\right)$ concentration, while LGRO groups tended to increase $(\mathrm{P}<0.05) \mathrm{T}_{4}$ concentration. Dietary LG and RO improved $(\mathrm{P}<0.05)$ total antioxidant capacity (TAOC) compared to CON group. Heavy infection was detected with Coccidia in the fecal samples of control group compared to LG and RO groups, while tented to have less quantity of oocysts output in LGRO group. It could be concluded that the addition of LG or RO in the diets may improve some blood metabolites, antioxidant status and immune response of Saidi ewes.
\end{abstract}

Keywords: Lemongrass, Roselle, blood metabolites, anticoccidial, lactating ewes

\section{INTRODUCTION}

In the last few years, there has been an increasing interest in isolating antioxidants from plant ingredients and using them in animal nutrition with the intention of replacing antibiotics. Lots of researches have been conducted to investigate the natural antioxidant activity of plant extracts. Herbs have been evaluated for their ability to alter ruminal fermentation and improve nutrient utilization in ruminants (Greathead, 2003; Wang et al., 2009). Phenolic compounds are among phytochemicals in plant extracts that may render their effects via inhibiting the oxidation reaction caused by oxidative stress and relief its consequences (Saltmarsh, 2003).

Lemongrass (Cymbopogon citratus) is one herb of interest, and it is widely used in tropical and subtropical countries in human foods (Tajidin et al., 2012). The basic structure of Lemongrass plant is "citral" (Schaneberg and Khan, 2002) and 1 to $2 \%$ essential oils based on dry matter (Carlson et al., 2001). Effects of Lemongrass on antibacterial (Valero and Salmeron, 2003), antioxidant (Mirghani et al., 2012), antinociceptive (Viana $\boldsymbol{e t}$ al., 2000), and antihyper- $\mathrm{NH}_{3}$-producing ruminal bacterial (Wanapat et al., 2008) activities have been studied. In addition, Hosoda et al. (2006) investigated the effects of the supplementation of Lemongrass leaf in the diet of Holstein steers and they found that the treatment had an effect on immune activity of steer. 
Roselle (Hibiscus sabdariffa) extract was reported to be used as an antibacterial, antifungal, diuretic, uricosuric, and mild laxative substance (Farnworth and Bunyapraphatsara, 1992). Anthocyanins and protocatechuic acid are among chemical constituents in Roselle that shown to have strong antioxidant (Kim et al., 2003) and antitumor effects (Choi $\boldsymbol{e t}$ al., 2008 and Sharma $\boldsymbol{e t}$ al., 2014). In addition, the components of Roselle extract exhibit antitumor characteristics, immune modulating and antileukemic effects (Müller $\boldsymbol{e} t$ al., 2007). In the same context Tsuda et al. (2000) reported that Roselle calyx had significant quantities of polyphenolic acids (1.7\% of dry weight), flavonoids (1.43\% of dry weight) and anthocyanins (2.5\% of dry weight).

On the other hand, coccidial infection is worldwide in sheep and goats, and coccidiosis can be a significant problem in young ages. The economic losses due to coccidial contamination are variable from low growth performance, reduction in productivity, death, morbidity, and the cost of prevention and treatment (Khodakaram-Tafti and Hashemnia, 2017). A number of plant-derived compounds have been effectively used as natural products to avoid the incidence of coccidiosis (Abudabos et al., 2017)

The information on the influence of herbs plants, such as Lemongrass and Roselle on antioxidant status and blood metabolites are very scarcity, especially on lactating ewes. Therefore, the objective of this experiment was to elucidate the influence of dietary dried Lemongrass and Roselle powder supplementation on some blood metabolites, antioxidant status and immune response of Saidi ewes.

\section{MATERIALS AND METHODS}

\section{Animals and treatments:}

The experiment is a part of research program of Animal Production Department and it was carried out at Animal Production Research Farm, Faculty of Agriculture, Assiut University, Assiut, Egypt. Lemongrass and Roselle herbs were obtained from local suppliers in Assiut city, Egypt.

Twenty-eight lactating Saidi ewes (at the $3^{\text {rd }}$ or $4^{\text {th }}$ lactating seasons and had an average body weighed $45.2 \pm 2 \mathrm{~kg}$ ) were used. The experiment lasted from 15 days before parturition and 60 days after parturition. Ewes were divided into four dietary groups ( 7 ewes each ).

The treatments were: (1) CON group, animals received control diet without additives, consist of concentrate mixture (CM) and wheat straw (60:40\% on dry matter (DM) basis); (2) LG group, animals fed control diet plus $4 \mathrm{~g}$ Lemongrass/ kg dry matter (DM) of CM: (3) RO group, animals fed control diet plus $4 \mathrm{~g}$ Roselle $/ \mathrm{kg}$ DM of CM and (4) LGRO group, animals fed control diet plus (2g Lemongrass $+2 \mathrm{~g}$ Roselle) $/ \mathrm{kg}$ $\mathrm{DM}$ of CM. The offered feeds were assessed to cover the maintenance and production requirements for each animal (NRC, 1985). The tested feed additives were mixed with concentrate mixture. The weight and chemical composition of the ingredients are shown in Table 1 . The concentrate mixture was offered for each animal individually once daily at $9.00 \mathrm{am}$, while wheat straw was offered at $12.00 \mathrm{hr}$. Ewes were weighed at the beginning of the experiment and over two weeks to adjust the feed requirements. Drinking water was freely available to the animals.

\section{Sampling and chemical analysis}

\section{Chemical analysis of feed ingredient:}

The ingredients and chemical composition of experimental diets used in this study are presented in Table (1). Feed Samples ingredient were analyzed for dry matter (DM), ash, crude protein (CP), and ether extract (EE) according to methods of AOAC (2012).while Van Soest et al.( 2010) method was used to determine the neutral detergent fiber (NDF) and acid detergent fiber (ADF). 
Table (1): The ingredients and chemical composition $(\mathrm{g} / \mathrm{kg})$ of control of ration.

\begin{tabular}{lc}
\hline Ingredient & $\%$ \\
\hline Wheat Straw & 400 \\
Maize Grain & 300 \\
Soybean Meal & 90 \\
Sunflower Meal & 72 \\
Wheat Bran & 120 \\
Limestone & 12 \\
Salt & 3 \\
Trace mineral and vitamin premix* & 3 \\
Total & 1000.00 \\
Chemical composition (g/kg DM) & \\
DM & 894.19 \\
OM & 822.69 \\
CP & 116.95 \\
EE & 28.46 \\
NDF & 424.23 \\
ADF & 235.71 \\
\hline
\end{tabular}

* The premix comprised (per $\mathrm{kg}$ ) 20,000,000 IU vitamin A, 200,000 IU vitamin D3, 10,000 mg vitamin E, 10,000 mg Fe, $2500 \mathrm{mg} \mathrm{Cu}, 20,000 \mathrm{mg} \mathrm{Mn,} 100 \mathrm{mg} \mathrm{Mo,} 100 \mathrm{mg} \mathrm{Co,} 800 \mathrm{mg} \mathrm{I}, 20,000 \mathrm{mg} \mathrm{Zn}$ and $100 \mathrm{mg} \mathrm{Se}$.

Dry matter $(D M)$, organic matter $(O M)$, crude protein $(C P)$, EE ether extract $(E E)$, neutral detergent fiber $(N D F)$, acid detergent fiber $(A D F)$.

\section{Blood Samples and analyses}

At the end of the experiment, $10 \mathrm{ml}$ of blood samples were collected from the jugular vein from each ewe, before morning feeding, in tubes containing potassium ethylene diamine tetra-acetic acid (K-EDTA). The blood samples were directly centrifuged at $3000 \mathrm{rpm}$ for $15 \mathrm{~min}$ and the plasma was separated and stored at $-20{ }^{\circ} \mathrm{C}$ until the chemical analyses of plasma total protein, albumin ( globulin concentration was obtained as the difference between the total protein and albumin concentration), total cholesterol, creatinine, lactic dehydrogenase (LDH), alanine aminotransferase (ALT) and aspartate aminotransferase (AST) enzymes using assay kits supplied by Diamond diagnostic, Egypt. Thyroid hormones (T3 and T4) concentrations were determined using enzyme-linked immunosorbent assay kits supplied by Biotecx, USA. Total antioxidant capacity (TAOC) was determined according to (Koracevic et al., 2001) while Hydrogen peroxide $\left(\mathrm{H}_{2} \mathrm{O}_{2}\right)$ was determined according to (Aebi, 1984).

\section{Examination of fecal samples for parasitic existence}

Fecal samples were collected from all groups at the beginning before administration of treatments and at the end of the experiment to analysis parasitic existence for Coccidia and the effect of treatments on Coccidial output in fecal samples. A total of 28 fecal samples from the four groups ( 7 animals/ each) were collected after defecation in a plastic sack (labeled with date and animal number). The samples were examined by sedimentation and floatation techniques according to Garcia and Bruckner (2001). The different diagnostic stages detected by microscopic examination and measured by an eye-piece micrometer. The culture of coccidian oocysts was tested and identification of different coccidian species were done according to (ARSLAN and TÜZER, 1998).

\section{Statistical Analysis}

The results were statistically analyzed using the SPSS statistical package 22 (SPSS Institute, Chigaco, IL, USA). The data were evaluated using the General Linear Models (GLM) procedure for analysis of variance and subjected to one-way ANOVA accompanied by Duncan's multiple range tests to detect the differences among the treatments. The data are presented as means \pm SE. Probability values less than $0.05(P<0.05)$ was considered significant. 


\section{Abdullah et al.}

\section{RESULTS AND DISCUSSION}

\section{Blood metabolites}

The effect of dietary lemongrass and Roselle on some blood plasma metabolites of Saidi ewes are presented in Table (2). Blood metabolites from the present study were within the references ranges reported by Boyd et al. (1984). The information on the effect of lemongrass and Roselle on blood metabolites are very scarcity, especially on lactating ewes. The results of previous research are mixed between high and low, depending on the type of animals and the type of production and quantities of herbs used. For example, no effect were observed in goats $(\mathrm{p}>0.05)$ with the inclusion of lemongrass and rosemary on serum total protein, albumin, globulin, urea-N, glutamic- pyruvic transaminase and glutamate-oxaloacetate transaminase concentration (kholif et al ., 2017) While, El-Bordeny et al. (2005) found that serum creatinine concentration didn't differ between the different groups of buffalo calves fed Lemongrass.

As shown in Table $(2)$, total protein and albumin concentrations decreased $(\mathrm{P}<0.05)$ in blood plasma of LGRO group compared to other ones. Also, ewes fed LG had the highest $(\mathrm{P}<0.05)$ level of globulin, while ewes fed LGRO had the lowest $(\mathrm{P}<0.05)$ level of globulin than other groups. Albumin/ globulin ratio did not differ significantly among treatments. These results agree with those reported by Khattab et al. (2017) who reported that plasma total protein did not affect in lactating Barki goats fed lemongrass and galangal supplemented diets. In contrast, (El-Ashry et al., 2006) found that serum total protein and albumin were increased $(\mathrm{P}<0.05)$ with adding lemongrass to buffalo calves but serum globulin was decreased. Our results may indicate that LG and RO supplementation groups had no adverse effect on energy metabolism in skeletal muscle (NE El-Bordeny, MA El-Ashry, 2005). It is recognized that the variation in albumin level mirrors the change in liver function and the presence of the fatty acids may affect muscle protein synthesis and protein admission (Englesbe et al., 2010).

There was a significant increase in total cholesterol concentration in LG and RO groups, while LGRO group had the lowest concentration of total cholesterol $(\mathrm{P}<0.05)$ compared with other ones. Similarly, many authors reported that cholesterol concentration was decreased in animals treated with lemongrass and Roselle (Badreldin et al., 2005; Kholif et al., 2017). Meanwhile, Agbafor and Akubugwo (2007) studied the effect of lemongrass on albino rats and observed that the elevated total cholesterol concentration was significantly $(\mathrm{P}<0.05)$ depressed in the animals given lemongrass. Lemongrass decreased serum total cholesterol concentration, the mechanism by which lemongrass supplementation decrease total cholesterol has not been wholly explored (Kholif et al., 2017).

Plasma creatinine levels in treatment groups decreased $(\mathrm{P}<0.05)$ compared to the CON group (Table 2). El-Bordeny et al. (2005) found that serum creatinine concentration didn't differ among the different groups of buffalo calves fed Lemongrass. This result cleared that herbs supplementations had no adverse effect on kidney function.

Table (2) showed an increase $(\mathrm{P}<.0 .05)$ in the concentrations of AST, ALT and LDH enzymes in lactating ewes fed LG and RO compared with those fed control diet and this increase was still within normal range. Also, there was an increase $(\mathrm{P}<.0 .05)$ in the activity of ALT, AST concentrations in LGRO group compared to the other ones. Ewes fed treated diets showed an increase $(\mathrm{P}<0.05)$ in the levels of plasma LDH enzyme compared with those fed CON diet. Ewes fed RO had the highest $(\mathrm{P}<.0 .05)$ level of LDH enzyme compared with other groups. These results indicated that tested additives to lactating ewes may have adverse effect on liver function and this result needs further investigation. In contrast, the supplementation of lemongrass in the diets had no significant effect on the concentrations of transaminase enzymes (AST and ALT), this results reported by Khattab et al. (2017).

Dietary RO decreased $(\mathrm{P}<0.05)$ the triioidothyronine $\left(\mathrm{T}_{3}\right)$ concentrations, while LGRO groups tended to increase $\mathrm{T}_{4}$ concentration (Table 2). The effect of fed LG and RO in the diets of animals on the activity of thyroid hormones is very limited. Thyroid hormone activity is considered crucial to sustaining the productive performance in domestic animals (growth, milk or hair fiber production). Variations in blood thyroid hormone concentrations are an indirect measure of the changes in thyroid gland action and circulating thyroid hormones can be considered as indicators of the metabolic and nutritional position of the animals (Todini, 2007). The highest levels of thyroid hormones $\left(\mathrm{T}_{3}\right.$ and $\mathrm{T}_{4}$ ), as shown in LG (for $\mathrm{T}_{3}$ ) and LGRO (for $\mathrm{T}_{4}$ ) diets ( Table 2) may increase the metabolic rate and improve the nutritional status in treated animals which reflected on animal health, welfare and production. 
Table (2): Blood plasma metabolites of lactating ewes fed Lemongrass and Roselle supplemented diets.

\begin{tabular}{|c|c|c|c|c|}
\hline \multirow[t]{2}{*}{ Item } & \multicolumn{4}{|c|}{ Treatment* } \\
\hline & $\mathrm{CON}$ & LG & RO & LGRO \\
\hline \multicolumn{5}{|l|}{ Blood metabolites } \\
\hline Total protein $(\mathrm{g} / \mathrm{dl})$ & $6.04^{\mathrm{a}} \pm 0.25$ & $5.48^{\mathrm{ab}} \pm 0.18$ & $5.44^{\mathrm{ab}} \pm 0.28$ & $4.96^{b} \pm 0.25$ \\
\hline Albumin $(\mathrm{Al})(\mathrm{g} / \mathrm{dl})$ & $3.10^{\mathrm{a}} \pm 0.15$ & $2.42^{\mathrm{ab}} \pm 0.18$ & $2.78^{\mathrm{ab}} \pm 0.11$ & $2.48^{\mathrm{b}} \pm 0.19$ \\
\hline Globulin $(\mathrm{Gl})(\mathrm{g} / \mathrm{dl})$ & $2.94^{\mathrm{ab}} \pm 0.22$ & $3.06^{\mathrm{a}} \pm 0.18$ & $2.64^{\mathrm{ab}} \pm 0.15$ & $2.46^{b} \pm 0.14$ \\
\hline $\mathrm{Al} / \mathrm{Gl}$ ratio & $1.08 \pm 0.11$ & $0.81 \pm 0.09$ & $1.07 \pm 0.08$ & $1.03 \pm 0.11$ \\
\hline Cholesterol(mg/dl) & $52.40^{\mathrm{b}} \pm 2.31$ & $66.60^{\mathrm{a}} \pm 3.12$ & $61.60^{\mathrm{a}} \pm 0.81$ & $42.80^{c} \pm 1.20$ \\
\hline Creatinine $(\mathrm{mg} / \mathrm{dl})$ & $1.14^{\mathrm{a}} \pm 0.15$ & $0.68^{\mathrm{b}} \pm 0.02$ & $0.68^{\mathrm{b}} \pm 0.05$ & $0.51^{\mathrm{b}} \pm 0.10$ \\
\hline \multicolumn{5}{|l|}{ Enzymes activities } \\
\hline $\operatorname{ALT}(\mathrm{U} / \mathrm{l})$ & $12.2^{\mathrm{c}} \pm 0.48$ & $18.20^{\mathrm{b}} \pm 1.39$ & $15.20^{\mathrm{bc}} \pm 1.52$ & $35.00^{\mathrm{a}} \pm 1.26$ \\
\hline $\mathrm{AST}(\mathrm{U} / \mathrm{l})$ & $60.60^{c} \pm 1.99$ & $86.80^{\mathrm{b}} \pm 5.50$ & $69.80^{c} \pm 3.51$ & $128.00^{\mathrm{a}} \pm 2.68$ \\
\hline $\mathrm{LDH}(\mathrm{U} / \mathrm{l})$ & $616.84^{\mathrm{c}} \pm 24.4$ & $778.74^{b} \pm 35.1$ & $913.12^{\mathrm{a}} \pm 21.6$ & $791.32^{\mathrm{b}} \pm 38.3$ \\
\hline \multicolumn{5}{|c|}{ The activity of thyroid hormones } \\
\hline $\mathrm{T} 3(\mathrm{ng} / \mathrm{mL})$ & $1.97^{\mathrm{a}} \pm 0.08$ & $2.14^{\mathrm{a}} \pm 0.16$ & $1.34^{\mathrm{b}} \pm 0.18$ & $1.80^{\mathrm{ab}} \pm 0.28$ \\
\hline $\mathrm{T} 4(\mathrm{nmol} / \mathrm{L})$ & $103.6^{\mathrm{b}} \pm 2.42$ & $87.92^{\mathrm{c}} \pm 3.37$ & $94.60^{\mathrm{bc}} \pm 5.58$ & $235.00^{\mathrm{a}} \pm 4.47$ \\
\hline \multicolumn{5}{|l|}{ Antioxidant status } \\
\hline $\mathrm{TAOC}(\mathrm{mmol} / \mathrm{L})$ & $0.39^{\mathrm{d}} \pm 0.02$ & $1.29^{\mathrm{a}} \pm 0.07$ & $0.97^{\mathrm{b}} \pm 0.02$ & $0.72^{c} \pm 0.04$ \\
\hline $\mathrm{H}_{2} \mathrm{O}_{2}(\mathrm{mmol} / \mathrm{L})$ & $0.20 \pm 0.001$ & $0.20 \pm 0.01$ & $0.20 \pm 0.012$ & $0.21 \pm 0.006$ \\
\hline
\end{tabular}

Each value represents an average of 7 samples $\pm S E$.

$a, b$, means at the same row with different superscript are significantly different $(P<0.05)$.

Con $=$ control diet; $L G$, control diet $+4 g$ Lemongrass $/ \mathrm{kg}$ of $D M ; R O$, control diet $+4 \mathrm{~g}$ dried Roselle/kg of DM and LGRO, control

$+2 \mathrm{~g}$ of Lemongrass and $2 \mathrm{~g}$ dried Roselle $/ \mathrm{kg}$ of DM. TAOC: Total antioxidant capacity and $\mathrm{H}_{2} \mathrm{O}_{2}$ : Hydrogen peroxide.

Total antioxidant capacity were significantly increased in treated ewes compared to untreated ewes (Table 2), while the concentration of $\mathrm{H}_{2} \mathrm{O}_{2}$ was not significantly affected by treatment. This result is confirmed that Lemongrass have antioxidant capacities such as free-radical scavenging metal ion chelation, and singlet oxygen quenching capacity (Velasco and Williams, 2011). In the same context, several studies both in vitro (Serrano et al., 2007) and in vivo (Mossalam et al., 2011) found antioxidant effect of Roselle extract. Such antioxidant activity is due to its strong scavenging effect on reactive oxygen and free radicals (Rocha De Souza $\boldsymbol{e t}$ al., 2007and Sia $\boldsymbol{e t}$ al., 2010), protection of cell from damage by lipid peroxidation (Farombi and Fakoya, 2005), decrease of glutathione depletion, rise of the liver and reduction blood activity of superoxide dismutase and catalase (Farombi and Fakoya, 2005) even though in the liver it improved superoxide dismutase, catalase, and glutathione and declined malondialdehyde (Mossalam et al., 2011). The effects were detected for both water and ethanolic extracts from Roselle flowers, as well as from the leaves or seeds (Mohd-Esa et al., 2010)(Sia et al., 2010)(Sia et al., 2010). (Hosoda et al., 2006) found that fed Lemongrass at $5 \%$ in the diet of Holstein steers affect the immunity system resulted from increasing antioxidant activity in plasma of steers. As well, Ojo et al. (2006) found that the extracts of Lemongrass produced significant $(\mathrm{P}<0.05)$ antioxidative effect by inhibiting the elevation of serum levels of malondialdehyde and catalase in rats.

\section{Parasitic existence in fecal samples}

In this study, the microscopical examination of fecal samples for parasitic protozoa detected two types of coccidia sp. were Eimeria bakuensis (ovina) and Eimeria ahsata.(Fig. 1). These results agrees with Arslan $\boldsymbol{e} t$ al. (1999) who reported that E. ahsata in Bursa province and E. bakuensis in the Aegean region. All fecal samples from all groups were found to be infected with Eimeria species. No samples were infected with only one species, the severity of infection tend to be the same in all groups except in LGRO group, which had a slight decrease in oocyst output. 


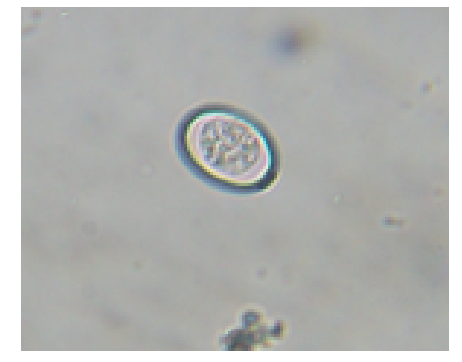

a) Oocyst of Eimeria bakuensis (x40)

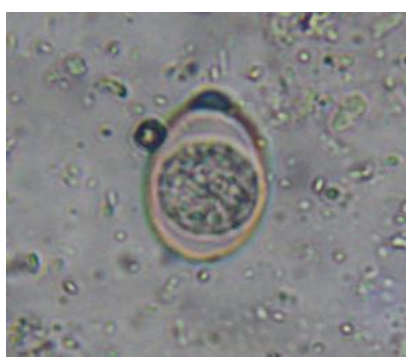

b) Oocyst of Eimeria ahsata (x40)

Fig. (1): Parasitic existence in fecal samples

The morphology of Eimeria sp: 1-Eimeria bakuensis (Fig. 1a): ellipsoidal in shape, the wall with smooth outer layer thick yellowish brown in color, micropyle present, it measured in average (8-5) width $\times(12-7.5)$ length. sporulation time :3 days. 2-Eimeria ahsata (Fig . 1b): Avoid in shape, smooth wall, yellowish brown in color, micropyle with distinct polar cap and polar body, it measured $(10-5)$ width $\times(17.5-10)$ length sporulation time: 3 days.

Actually, there is no sufficient data on the effect of Lemongrass or Roselle as an anticoccidial agent in feeding. Furthermore, clinically, normal sheep and goats often shed coccidial oocyst (Khodakaram-Tafti and Hashemnia, 2017). The dimension of coccidial output in LGRO had a positive anticoccidial effect on ewes, so we advise further research to study the ascending grade of these compounds as an anticoccidial agent.

\section{CONCLUSION}

Dietary Lemongrass or Roselle may improved some of blood metabolites, antioxidant status and had positive anticoccidial effect on Saidi ewes.

\section{ETHICAL APPROVAL}

All applicable international, national, and/or institutional guidelines for the care and use of animals were followed.

\section{CONFLICT OF INTEREST}

The authors declare that they have no conflict of interest.

\section{REFERENCES}

Abudabos, A.M., Alyemni, A.H., Swilam, E.O., Al-Ghadi, M.Q., 2017. Comparative Anticoccidial Effect of some Natural Products against Eimeria spp. Infection on Performance Traits, Intestinal Lesion and Occyte Number in Broiler. Pakistan Journal of Zoology 49, 1989-1995.

Aebi, H., 1984. [13] Catalase in vitro, in: Methods in Enzymology. Elsevier, pp. 121-126. 
Agbafor, K.N., Akubugwo, E.I., 2007. Hypocholesterolaemic effect of ethanolic extract of fresh leaves of Cymbopogon citratus (lemongrass). African Journal of Biotechnology 6, 596-598.

AOAC, 2012. Official methods of analysis, Association of Official Analytical Chemists, Gaithersburg, USA, 19th ed.

ARSLAN, M.Ö., TÜZER, E., 1998. Prevalence of bovine eimeridosis in Thracia, Turkey. Turkish Journal of Veterinary and Animal Sciences 22, 161-164.

Badreldin, H.A., Naser Al, W., Gerald, B., 2005. Phytochemical, pharmacological and toxicological aspects of Hibiscus sabdariffa L.: a review. Phytotherapy Research 19, 369-375.

Boyd, J.B., Taylor, G.I., Corlett, R., 1984. The vascular territories of the superior epigastric and the deep inferior epigastric systems. Plastic and Reconstructive Surgery. https://doi.org/10.1097/00006534198401000-00001

Carlson, L.H.C., Machado, R.A.F., Spricigo, C.B., Pereira, L.K., Bolzan, A., 2001. Extraction of lemongrass essential oil with dense carbon dioxide. Journal of Supercritical Fluids. https://doi.org/10.1016/S0896-8446(01)00085-7

Choi, J.W., Lim, H.Y., Chang, M.R., Cheon, J.Y., Kim, Y.S., 2008. Anti-tumor immunity induced by tumor cells express a membrane-bound form of IL-2 and SDF-1. Animal Cells and Systems 12, 193-201. https://doi.org/10.1080/19768354.2008.9647173

El-Ashry, M.A., El-Bordeny, N.E., Khattab, H.M., El-Sayed, H.M., 2006. Effect of dietry supplemented with medicinal herbs on nutrient digestibility and some blood metabolites of buffalo calves. Egyptian J. Nutrition and Feeds 9, 179-191.

Englesbe, M.J., Patel, S.P., He, K., Lynch, R.J., Schaubel, D.E., Harbaugh, C., Holcombe, S.A., Wang, S.C., Segev, D.L., Sonnenday, C.J., 2010. Sarcopenia and mortality after liver transplantation. Journal of the American College of Surgeons 211, 271-278.

Farnworth, R. N., \& Bunyapraphatsara, N., 1992. Garcinia mangostana Linn. in Thai medicinal plants. Prachachon Bangkok.

Farombi, E.O., Fakoya, A., 2005. Free radical scavenging and antigenotoxic activities of natural phenolic compounds in dried flowers of Hibiscus sabdariffa L. Molecular Nutrition and Food Research. https://doi.org/10.1002/mnfr.200500084

Garcia, L.S., Bruckner, D.A., 2001. Diagnostic medical parasitology. Washington, DC 131-135.

Greathead, H., 2003. Plants and plant extracts for improving animal productivity. Proceedings of the Nutrition Society. https://doi.org/10.1079/pns2002197

Hosoda, K., Kuramoto, K., Eruden, B., Nishida, T., Shioya, S., 2006. The effects of three herbs as feed supplements on blood metabolites, hormones, antioxidant activity, IgG concentration, and ruminai fermentation in holstein steers. Asian-Australasian Journal of Animal Sciences.

Khattab, M.S.A., El-Zaiat, H.M., El Tawab, A.M.A., Matloup, O.H., Morsy, A.S., Abdou, M.M., Ebeid, H.M., Attia, M.F.A., Sallam, S.M.A., 2017. Impact of lemongrass and galangal as feed additives on performance of lactating Barki goats. International Journal of Dairy Science. https://doi.org/10.3923/ijds.2017.184.189

Khodakaram-Tafti, A., Hashemnia, M., 2017. An overview of intestinal coccidiosis in sheep and goats. Rev. Med. Vet.(Toulouse) 167, 9-20.

Kholif, A.E., Matloup, O.H., Morsy, T.A., Abdo, M.M., Abu Elella, A.A., Anele, U.Y., Swanson, K.C., 2017. Rosemary and lemongrass herbs as phytogenic feed additives to improve efficient feed utilization, manipulate rumen fermentation and elevate milk production of Damascus goats. Livestock Science. https://doi.org/10.1016/j.livsci.2017.08.001

Kim, D.-O., Jeong, S.W., Lee, C.Y., 2003. Antioxidant capacity of phenolic phytochemicals from various cultivars of plums. Food chemistry 81, 321-326.

Koracevic, D., Koracevic, G., Djordjevic, V., Andrejevic, S., Cosic, V., 2001. Method for the measurement of antioxidant activity in human fluids. Journal of clinical pathology 54, 356-361. 
Mirghani, M.E.S., Liyana, Y., Parveen, J., 2012. Bioactivity analysis of lemongrass (Cymbopogan citratus) essential oil.

Mohd-Esa, N., Hern, F.S., Ismail, A., Yee, C.L., 2010. Antioxidant activity in different parts of roselle (Hibiscus sabdariffa L.) extracts and potential exploitation of the seeds. Food Chemistry 122, 1055-1060.

Mossalam, H.H., Abd-El Aty, O.A., Morgan, E.N., Youssaf, S., Mackawy, A.M.H., 2011. Biochemical and ultra structure studies of the antioxidant effect of aqueous extract of hibiscus sabdariffa on the nephrotoxicity induced by organophosphorous pesticide (malathion) on the adult albino rats. Journal of American Science 7, 561-572.

Müller, B., Kraus, J., Franz, G., 2007. Chemical Structure and Biological Activity of Water-Soluble Polysaccharides from Cassia angustifolia Leaves. Planta Medica 55, 536-539. https://doi.org/10.1055/s2006-962088

NE El-Bordeny, MA El-Ashry, H.K., 2005. Effect some medicinal herbs on buffalo calves performance from first week old till weaning tle. Egypt J Anim Nutrit Feeds,.

NRC, 1985. Nutrient requirements of sheep. National Academies.

Ojo, O.O., Kabutu, F.R., Bello, M., Babayo, U., 2006. Inhibition of paracetamol-induced oxidative stress in rats by extracts of lemongrass (Cymbropogon citratus) and green tea (Camellia sinensis) in rats. African Journal of Biotechnology 5.

Rocha De Souza, M.C., Marques, C.T., Guerra Dore, C.M., Ferreira Da Silva, F.R., Oliveira Rocha, H.A., Leite, E.L., 2007. Antioxidant activities of sulfated polysaccharides from brown and red seaweeds, in: Journal of Applied Phycology. https://doi.org/10.1007/s10811-006-9121-z

Saltmarsh, M., 2003. Phytochemicals and Phytopharmaceuticals, 2000 Edited by Fereidoon Shahidi and Chi-Tang Ho AOCS Press ISBN $189399705 \quad 7$ Price US \$135. Nutrition Bulletin. https://doi.org/10.1046/j.1467-3010.2001.0143b.x

Schaneberg, B.T., Khan, I.A., 2002. Comparison of extraction methods for marker compounds in the essential oil of lemon grass by GC. Journal of Agricultural and Food Chemistry 50, 1345-1349. https://doi.org/10.1021/jf011078h

Serrano, J., Goñi, I., Saura-Calixto, F., 2007. Food antioxidant capacity determined by chemical methods may underestimate the physiological antioxidant capacity. Food Research International 40, 15-21.

Sharma, S., Zhu, L., Yang, S.C., Zhang, L., Lin, J., Hillinger, S., Gardner, B., Reckamp, K., Strieter, R.M., Huang, M., Batra, R.K., Dubinett, S.M., 2014. Cyclooxygenase 2 Inhibition Promotes IFN- -Dependent Enhancement of Antitumor Responses. The Journal of Immunology 175, 813-819. https://doi.org/10.4049/jimmunol.175.2.813

Sia, J., Yee, H. Ben, Santos, J.H., Abdurrahman, M.K.A., 2010. Cyclic voltammetric analysis of antioxidant activity in cane sugars and palm sugars from Southeast Asia. Food Chemistry. https://doi.org/10.1016/j.foodchem.2009.05.030

Tajidin, N.E., Ahmad, S.H., Rosenani, A.B., Azimah, H., Munirah, M., 2012. Chemical composition and citral content in lemongrass (Cymbopogon citratus) essential oil at three maturity stages. African Journal of Biotechnology 11, 2685-2693. https://doi.org/10.5897/AJB11.2939

Todini, L., 2007. Thyroid hormones in small ruminants: effects of endogenous, environmental and nutritional factors. Animal 1, 997-1008.

Tsuda, T., Horio, F., Osawa, T., 2000. The role of anthocyanins as an antioxidant under oxidative stress in rats. Biofactors 13, 133-139.

Valero, M., Salmeron, M.C., 2003. Antibacterial activity of 11 essential oils against Bacillus cereus in tyndallized carrot broth. International journal of food microbiology 85, 73-81.

Van Soest, P.J., Robertson, J.B., Lewis, B.A., 2010. Methods for Dietary Fiber, Neutral Detergent Fiber, and Nonstarch Polysaccharides in Relation to Animal Nutrition. Journal of Dairy Science. https://doi.org/10.3168/jds.s0022-0302(91)78551-2

Velasco, V., Williams, P., 2011. Improving meat quality through natural antioxidants. Chilean journal of 
agricultural research 71,313 .

Viana, G.S.B., Vale, T.G., Pinho, R.S.N., Matos, F.J.A., 2000. Antinociceptive effect of the essential oil from Cymbopogon citratus in mice. Journal of Ethnopharmacology 70, 323-327.

Wanapat, M., Cherdthong, A., Pakdee, P., Wanapat, S., 2008. Manipulation of rumen ecology by dietary lemongrass (Cymbopogon citratus Stapf.) powder supplementation. Journal of Animal Science 86, $3497-$ 3503. https://doi.org/10.2527/jas.2008-0885

Wang, C.J., Wang, S.P., Zhou, H., 2009. Influences of flavomycin, ropadiar, and saponin on nutrient digestibility, rumen fermentation, and methane emission from sheep. Animal Feed Science and Technology. https://doi.org/10.1016/j.anifeedsci.2008.03.008

\title{
تأثثر إضافة حشيشة الليمون والكركديه في عليقة النعاج على خصائص مكونات الام و كمضادات للكوكسيديا
}

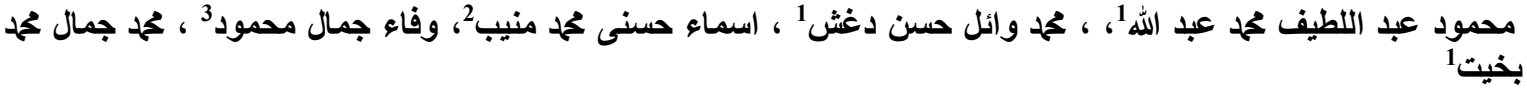
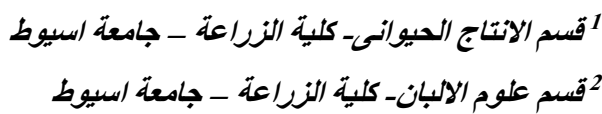 \\ 3قسم الطفيليات كلية الطب البيطرى - جامعة الوادى الجديل
}

أجريت هذه التجربة بهدف دراسة تاثير إضافة حشيشة الليمون والكركديه كمصادر لمضادات الأكسدة في عليقة النعاج الحلابة. تم

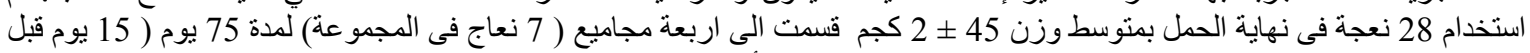
الو لادة و 60 يوم بعد الو لادة) وكانت العليقة المقدمة لهذه المجمو عات كألاتى: مجموعة الكنترول: المخلوط المركز : تبن القمح ( 60: 40 على لى لئل

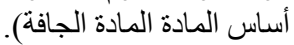

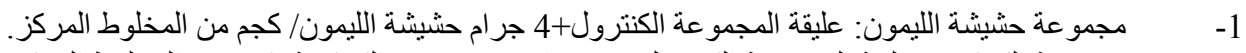

2-

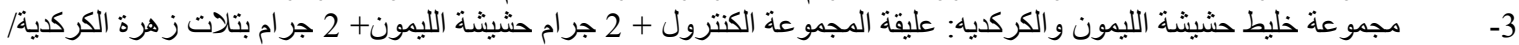

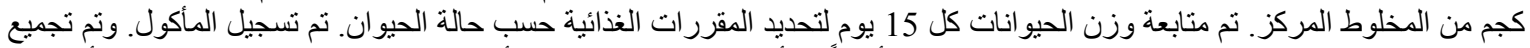

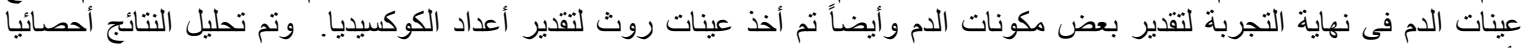

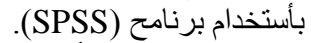

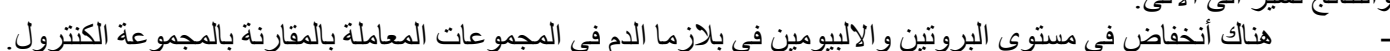

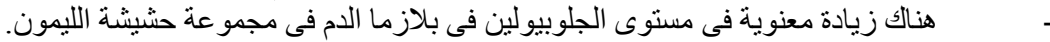

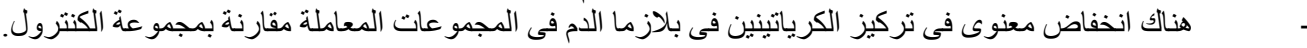

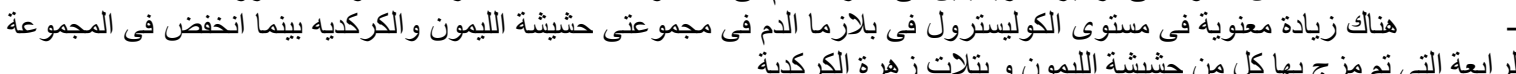

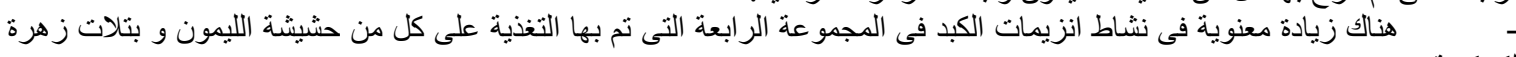

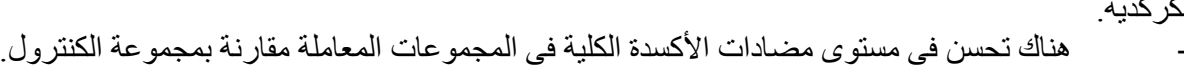

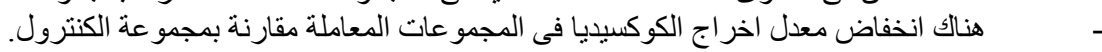

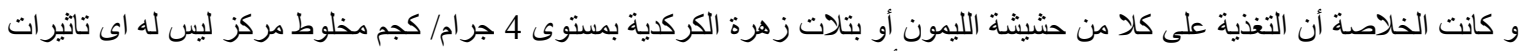

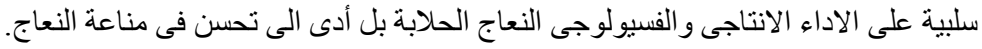

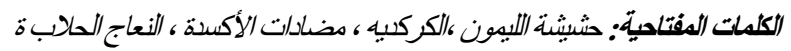

